\title{
COVID-19 and violence: a research call to action
}

\author{
Dabney P. Evans ${ }^{*}$ (D)
}

\begin{abstract}
COVID-19 related guidelines and movement restrictions are designed to protect the public's health and reduce disease transmission; yet, COVID-19 related restrictions on movement including social distancing, isolation, quarantine, and shelter-in-place orders have an unknown effect on violence and abuse within relationships. As the pandemic has progressed, many have justifiably speculated that such restrictions may pose a danger to the safety and well-being of people experiencing such violence. Early in the pandemic, countries hard hit by COVID-19 began raising the alarm bell about the impacts of the disease on IPV occurrence. Police in China report that $90 \%$ of the causes of recent IPV cases could be attributed to the COVID-19 epidemic. Rising fears and anxiety about prolonged movement restrictions, increased economic strain and diminished health care capacity to support survivors are among the potential reasons for such dramatic effects. Under normal circumstances: low income, unemployment, economic stress, depression, emotional insecurity and social isolation are all risk factors for using violence against partners. Many of these factors may worsen in the context of COVID-19. Despite the urgency in addressing COVID-19, existing health concerns like Intimate Partner Violence (IPV) persist-and may well be worsened by the virus. We simply do not yet know the effects of COVID-19 on violence, nor do we know which interventions work best to prevent and respond to it within the context of the pandemic. The vast majority of information available about IPV and violence during the pandemic has been based on anecdotal reports. The call to action for the research community is clear. We must systematically measure the effects of COVID-19 and movement related restrictions on violence. As always when researching violence, serious consideration must be given to ethics and safety. Violence researchers must mobilize to investigate the impacts of COVID-19 on violence and human health.
\end{abstract}

Keywords: COVID-19, Violence against women, Intimate partner violence, Pandemic, Emergencies, Research

COVID-19 related guidelines and movement restrictions are designed to protect the public's health and reduce disease transmission; yet, COVID-19 related restrictions on movement including social distancing, isolation, quarantine, and shelter-in-place orders have an unknown effect on violence and abuse within relationships. As the pandemic has progressed, many have justifiably speculated that such restrictions may pose a danger to the safety and well-being of people experiencing such violence. Intimate

*Correspondence: Dabney.evans@emory.edu

Hubert Department of Global Health, Emory University, 1518 Clifton Rd, NE, Atlanta, GA 30322, USA
Partner Violence (IPV) includes physical, sexual, and psychological abuse by a past or current intimate partner [1]. IPV is incredibly common; for example, in the United States, nearly 20 people every minute are physically abused by an intimate partner [2]. While physical violence is the most obvious form of abuse, IPV can also include less identifiable forms of abuse that either center around intimidation and control or are an exacerbation of those who use physicality when they "fight" [1]. Such controlling behaviors are likely to be exacerbated during periods of movement restriction with the pandemic being used as a justification for increased control. 
Early in the pandemic, countries hard hit by COVID19 began raising the alarm bell about the impacts of the disease on IPV occurrence. France saw a 36\% increase in the number of reported IPV cases and one city in China reported a two-fold increase in IPV cases in one month following movement restrictions [3, 4]. Police in China reported that $90 \%$ of the causes of recent IPV cases could be attributed to the COVID-19 epidemic [4]. Rising fears and anxiety about prolonged movement restrictions, increased economic strain and diminished health care capacity to support survivors are among the potential reasons for such dramatic effects.

Under normal circumstances: low income, unemployment, economic stress, depression, emotional insecurity and social isolation are all risk factors for using violence against partners. Many of these factors may worsen in the context of COVID-19 [5, 6]. Notably, increased social isolation is an actively-and justifiably-promoted tactic to prevent disease transmission [7]. At the same time, isolation is sometimes used by those who use violence against partners to keep family problems secret or to exert power and control [1]. It also means that women who are experiencing violence have less chance to reach out to co-workers or extended family members as well as to other helping resources when they have to stay home [8]. Yet, those isolated at home still have options, albeit more limited than usual. Those in violent relationships may feel that leaving during a pandemic is unfeasible or undesirable. For those people, safety planning apps like myPlan - which is available app free in all app storescan be used to take a homicide risk assessment (the Danger Assessment) and create a personalized safety plan [9-11]. Family members and friends can also use myPlan on behalf of people they are worried about.

Despite the urgency in addressing COVID-19, existing health concerns like IPV persist-and may well be worsened by the virus [12]. Immediate interventions such as the use of code words at pharmacies, and exemptions on movement restrictions for IPV survivors have reportedly shown promise in responding to survivors immediate needs [13]. Such interventions may also assist in repurposing industries hit hard by the economic effects of COVID-19. For example, the provisions of hotel rooms for survivors by the French government is at once serving survivors immediate needs and bolstering support for the weakened hospitality industry; similar efforts have been supported by hotel associations in the US $[3,14]$.

However promising such programs may be a glaring gap remains: we simply do not know the effects of COVID-19 on violence, nor do we know which interventions work best to prevent and respond to it within the context of the pandemic. The vast majority of information available about IPV and violence during the pandemic has been based on anecdotal reports $[3,4,8,13]$. The call to action for the research community is clear. We must systematically measure the effects of COVID-19 and movement related restrictions on violence. This includes not only incidence of IPV-and other forms of gender-based violence-but also the risk factors for violence perpetration, victimization and the socio-contextual determinants influencing the occurrence of violence during this time. As always when researching violence, serious consideration must be given to ethics and safety [15-17]. Fortunately, several UN agencies have already offered resources and guidance on how to safely and ethically conduct research during this period [18-20].

Admittedly, the typical timeline for research is dramatically slower than social phenomena even in the absence of a pandemic. A lack of data should not prevent the development and implementation of new and adapted programs to respond to violence during this period. After all, we already know how prevalent it is; violence itself is a pandemic [2123]. Scientists focused directly on addressing COVID-19 have coalesced to address the need for testing, treatments and a vaccine [24]. So too must violence researchers mobilize to investigate the impacts of COVID-19 on violence and human health.

\section{Abbreviations \\ COVID-19: Corona virus disease 2019; IPV: Intimate partner violence; UN: United Nations; US: United States.}

\section{Acknowledgements \\ Not applicable.}

\section{Authors' contributions}

DPE designed and wrote the work in its entirety. She has approved the submitted version and is personally accountable for her contributions.

\section{Authors' information}

DPE is an Associate Professor of Global Health in the Rollins School of Public Health at Emory University.

\section{Funding}

This work was unfunded.

\section{Availability of data and materials}

Data sharing not applicable to this article as no datasets were generated or analyzed during the current study.

\section{Ethics approval and consent to participate} Not applicable.

\section{Consent for publication}

Not applicable.

\section{Competing interests}

The author declares that she has no competing interests.

Received: 11 June 2020 Accepted: 2 November 2020

Published online: 10 November 2020 


\section{References}

1. World Health Organization. Understanding and addressing violence against women: intimate partner violence. World Health Organization; 2012.

2. Black M, Basile K, Breiding M, Smith S, Walters M, Merrick M, Chen J, Stevens M. National intimate partner and sexual violence survey: 2010 summary report.

3. Godin M. France to house domestic abuse victims in hotels amid lockdown. Time; 2020 [cited 2020May29]. https://time.com/5812990/franc e-domestic-violence-hotel-coronavirus/.

4. Wanqing Z. Domestic violence cases surge during COVID-19 epidemic Sixth Tone; 2020 [cited 2020May29]. https://www.sixthtone.com/ news/1005253/domestic-violence-cases-surge-during-covid-19-epide mic.

5. Centers for Disease Control and Prevention. Risk and Protective Factors Intimate Partner Violence. Violence prevention. Centers for Disease Control and Prevention; 2019 [cited 2020May29]. https://www.cdc.gov/viole nceprevention/intimatepartnerviolence/riskprotectivefactors.html.

6. Godin M. How coronavirus is affecting victims of domestic violence. Time; 2020 [cited 2020May29]. https://time.com/5803887/coronavirus-domes tic-violence-victims/.

7. Centers for Disease Control and Prevention. Social Distancing, Quarantine, and Isolation. Centers for Disease Control and Prevention; 2020 [cited 2020May29]. https://www.cdc.gov/coronavirus/2019-ncov/preve nt-getting-sick/social-distancing.html.

8. Taub A. A new COVID-19 crisis: domestic abuse rises worldwide The New York Times; 2020 [cited 2020May29]. https://www.nytim es.com/2020/04/06/world/coronavirus-domestic-violence.html?campa ign_id $=2$.

9. The Johns Hopkins University School of Nursing. myPlan App. The Johns Hopkins University School of Nursing; 2019 [cited 2020May29]. https:// www.myplanapp.org/.

10. Campbell JC, Webster DW, Glass N. The danger assessment: validation of a lethality risk assessment instrument for intimate partner femicide. J Interpers Violence. 2009;24(4):653-74.

11. Glass N, Eden KB, Bloom T, Perrin N. Computerized aid improves safety decision process for survivors of intimate partner violence. J Interpers Violence. 2010;25(11):1947-64.

12. van Gelder N, Peterman A, Potts A, O'Donnell M, Thompson K, Shah N, Oertelt-Prigione S. COVID-19: reducing the risk of infection might increase the risk of intimate partner violence. EClinicalMedicine. 2020;21:100348.

13. Kottasová I. Women are using code words at pharmacies to escape domestic violence. CNN. CNN; 2020 [cited 2020May29]. https://www.cnn com/2020/04/02/europe/domestic-violence-coronavirus-lockdown-intl/ index.html.

14. Rozman H. Letters to the Editor: How L.A.'s hotel industry is stepping up in the COVID-19 crisis. Los Angeles Times; 2020 [cited 2020May29]. https ://www.latimes.com/opinion/story/2020-04-12/hotel-industry-is-stepp ing-up-in-the-covid-19.

15. Ellsberg MC, Heise L. Researching violence against women: practical guidelines for researchers and activists. Geneva: World Health Organization; 2005.

16. World Health Organization. Ethical and safety recommendations for intervention research on violence against women: building on lessons from the WHO publication putting women first: ethical and safety recommendations for research on domestic violence against women. Geneva: $\mathrm{WHO} ; 2016$

17. World Health Organization. Putting women first: ethical and safety recommendations for research on Domestic Violence Against Women. Geneva: World Health Organization; 2001.

18. Peterman A, Bhatia A, Guedes A. Remote data collection on violence against women during COVID-19: a conversation with experts on ethics, measurement \& research priorities (Part 1). UNICEF Innocenti. UNICEF; [cited 2020May29]. https://www.unicef-irc.org/article/1997-remote-datacollection-on-violence-against-women-during-covid-19-a-conversati on-with.html.

19. UN Women. COVID-19 and ending violence against women and girls. UN Women; 2020. https://www.unwomen.org/en/digital-library/publicatio ns/2020/04/issue-brief-covid-19-and-ending-violence-against-women -and-girls.

20. Human Reproduction Programme. COVID-19 and violence against women: what the health sector/system can do. World Health Organization; 2020. https://www.who.int/reproductivehealth/publications/emerg encies/COVID-19-VAW-full-text.pdf.

21. Krug EG, Mercy JA, Dahlberg LL, Zwi AB. The world report on violence and health. The Lancet. 2002;360(9339):1083-8.

22. Devries KM, Mak JY, Garcia-Moreno C, Petzold M, Child JC, Falder G, Lim S, Bacchus $L$, Engell RE, Rosenfeld L, Pallitto $C$. The global prevalence of intimate partner violence against women. Science. 2013;340(6140):1527-8.

23. Fulu E, Jewkes R, Roselli T, Garcia-Moreno C. Prevalence of and factors associated with male perpetration of intimate partner violence: findings from the UN Multi-country Cross-sectional Study on Men and Violence in Asia and the Pacific. Lancet Glob Health. 2013;1(4):e187-207.

24. Apuzzo M, Kirkpatrick D. Covid-19 changed how the world does science, together. The New York Times; 2020 [cited 2020May29]. https://www. nytimes.com/2020/04/01/world/europe/coronavirus-science-researchcooperation.html.

\section{Publisher's Note}

Springer Nature remains neutral with regard to jurisdictional claims in published maps and institutional affiliations.
Ready to submit your research? Choose BMC and benefit from:

- fast, convenient online submission

- thorough peer review by experienced researchers in your field

- rapid publication on acceptance

- support for research data, including large and complex data types

- gold Open Access which fosters wider collaboration and increased citations

- maximum visibility for your research: over $100 \mathrm{M}$ website views per year

At BMC, research is always in progress.

Learn more biomedcentral.com/submissions 